with many uses. The remaindor of Van de Graaff's scientific career was dedicated to the improvement and uses of high voltage generators.

In 1931 he followed K. T. Compton to the Massachusetts Institute of Technology, and during the war as director of the High Voltage Radiographic Project there for the Office of Scientific Research and Development, with the help of a small group, ho built and installed five generators. This experience suggested that electrostatic generators could be produced commercially as standard instruments for use in nuclear research and medicine and led to the formation in $\mathbf{1 9 4 6}$ of the High Voltage Engineering Corporation of which Van de Graaff and Drs. John Trump and Denis Robinson were directors. The phenomenal success and growth of the company are well known and its products are to be found in physical rosearch laboratories and hospitals all over the world. Van de Graaff served the company first as chief physicist and later as chief scientist, and was responsible for many of its major scientific advances, such as the recent ingenious insulated core transformor. His most recent work was dirested to the improvement of rotating electrical genera. tors both for the direct production of high voltages and for large powers, and with his usual acumen he was able to circumvent some of the limitations of conventional machines.

As a scientist who left his mark on the science of his generation Van do Graaff received many academic honours including the Elliot Cresson Medal of the Franklin Institute; the Naval Ordnance Development Award; the Dudell Medal of the Physical Society; the Tom W. Bonnor Prize of the American Physical Society, and honorary degrees from the Univorsitios of Alabama, Florida and Utrecht.

Van de Graaff was among the most courteous and eonsiderate of men; he evoked deep affection, admiration and loyalty in friends and colleagues alike, and his conversation, both scientific and social, was stimulating, provocative, just and vivid. Those privileged to know him will, in retrospect, echo Reynolds' tribute to Johnson - "He qualifiod my mind to think justly".

$$
\text { L. G. H. HuXLeY }
$$

\section{Dr. Nabor Carrillo}

Dr. Nabor Carrillo, who died on February 19 at the age of 54, was a prominent Mexican seientist. He had ropresented his country at the U.N. Atomic Energy Commission. He began to teach at the National University of Mexien when he was still a student. Dr. Sotero Prieto, a pioneer in modern mathematics, rogarded Carrillo as his most distinguishod student. In 1942, Carrillo comploted his doctoral thesis at Harvard University.

His best known work includes the first quantitative explanation of the subsidence of Mexico City and the analysis of the subsidence of Long Boach, California. In the latter case his theory of "tension centres" was an important contribution to soil mechanics. One of his notable achievements was the design of the Angostura arch dam, the first such enterprise to bo undertaken by Mexioan engineers. Carrillo's many publications in physies, applied mathomatics and engineering covered such topics as elasticity, plasticity, soil mochanics and the strength of materials.

Carrillo was a professor at the National University of Mexico-here he was for several years co-ordinator of scientific research-at Harvard University and at the universities of Now York and Havana. In 1946 he was named adviser on nuclear energy to the Moxican government, and represented his country at the U.N. Atomic Energy Commission and at the experiments at Bikini. From 1956 he was a member of the board of diroctors of his country's Nuclear Energy Commission. In 1957 he received Mexicu's National Prize for science; he was twice prosident of the Mexican National Academy of Scionces, and was also president of tho Mexican Mathematical Society. Carrillo was awarded a number of honours, including the Humboldt Medal and the Légion d'Honneur, but he regarded his eight years, from 1953-61, as Rector of the National University of Mexico as the highest honour he ever roceived.

\section{Dr. Joseph Bamforth}

The death of Dr. Joseph Bamforth at the age of 78 on February 10, 1967, deprived clinical pathology of one of its greatest exponents and of one of its most lovable characters. After graduating M.B., Ch.B. from the University of Liverpool in 1911, and taking the Conjoint Diploma in the same yoar, ho hold appointments as house physician and houso surgeon in Liverpool Royal Infirmary before becoming a Holt Fellow in Pathology and later lecturer in the university. Ho proceeded M.D. in 1914, his thesis being a histological study of the cyclical changes in the endometrium, thus pointing towards an interest in gynaecological pathology which he was to exploit to the full in lator years. The First World War, however. involved service in the forty-ninth Goneral Hospital, British Salonika Force, which not only turned his interosts for the time being towards bacteriology but also had a profound effect on his later career, in that association with L. S. Dudgeon, consulting pathologist to this force, resulted in Bamforth becoming assistant bacteriologist at St. Thomas's Hospital, London, in 1922. In 1924 he took the M.R.C.P. and described the first British cases of dysentery caused by Sonno's bacillus. Studies on atypical Escherichia coli and invostigation of Staphylococcus aureus with the production of a "toxoid" for the treatment of furunculosis (which was still in demand for some years after the introduction of antibiotics) followed, together with publications on megakaryocytic myclosis and aplastic andemia. After Dudgeon's death in 1938, Bamforth became director of clinical pathology at St. Thomas's, and during the Second World War he also served as an Emergency Medical Service sector pathologist when the hospital was ovacuated to Hydestile, near Godalming. In 1940 he was elected F.R.C.P.

After returning to London at the end of the war, he concentrated more on histology and especially on diagnostic eytology, in which he had been interested since Dudgeon developed the technique, and to which he contributed much original work culminating in the publication of his book, Cytological Diagnosis in Medical Practice. in 1966 -when he was 77 years old.

He retired from St. Thomas's in 1953, but his work continued at the Imperial Cancer Research Fund, Royal College of Surgeons, and at King's Colloge Hospital. Election as F.R.C.O.G. in 1958 and as first President of the British Society for Clinical Cytology in 1962 gavo him great pleasure.

Such an account of Joe's public achievements gives little idea of his outstanding personal qualities which included a charming and genuine modesty and an enthusiasm for his work which he was able to communicate-without conscious offort on his own part-to students, colloagues or even the first person he happened to mcet after making a particularly interesting discovery in his laboratory. His application of laboratory investigations in clinical diagnosis was aided by an astonishing memory of details of previous cases, a characteristic which also made him a stimulating toacher. Neither his enthusiasm nor his vast experience, however, deviated him from his course of strict scientific honosty.

Joo was a great pathologist; his kindness, generosity and wit will be remembered with affection and gratitude by his very many friends who knew him also as a great man.
K. R. DEmpster 